\title{
Plastic debris in the coastal environment: The invincible threat? Abundance of buried plastic debris on Malaysian beaches
}

Waste Management \& Research

2015. Vol. 33(9) 812-821

(c) The Author(s) 2015

Reprints and permissions

sagepub.co.uk/journalsPermissions.nav

DOI: $10.1177 / 0734242 \times 15588587$

wmr.sagepub.com

(S) SAGE

\author{
SH Fauziah, IA Liyana and P Agamuthu
}

\begin{abstract}
Studies on marine debris have gained worldwide attention since many types of debris have found their way into the food chain of higher organisms. Thus, it is crucial that more focus is given to this area in order to curb contaminations in sea food. This study was conducted to quantify plastic debris buried in sand at selected beaches in Malaysia. Marine debris was identified according to size range and distribution, and this information was related to preventive actions to improve marine waste issues. For the purpose of this study, comparison of plastic waste abundance between a recreational beach and fish-landing beaches was also carried out, since the different beach types represent different activities that produce debris. Six beaches along the Malaysian coastline were selected for this study. The plastic types in this study were related to the functions of the beach. While recreational beaches have abundant quantities of plastic film, foamed plastic including polystyrene, and plastic fragment, fish-landing beaches accumulated line and foamed plastic. A total of 2542 pieces $\left(265.30 \mathrm{~g} \mathrm{~m}^{-2}\right)$ of small plastic debris were collected from all six beaches, with the highest number from Kuala Terengganu, at 879 items $\mathrm{m}^{-2}$ on Seberang Takir Beach, followed by Batu Burok Beach with 780 items $\mathrm{m}^{-2}$. Findings from studies of Malaysian beaches have provided a clearer understanding of the distribution of plastic debris. This demonstrates that commitments and actions, such as practices of the 'reduce, reuse, recycle' (3R) approach, supporting public awareness programmes and beach clean-up activities, are essential in order to reduce and prevent plastic debris pollution.
\end{abstract}

\section{Keywords}

Marine debris, fragmented plastics, waste management, recreational beaches, fishing beach

\section{Introduction}

Continuous environmental degradation has resulted in the shortening of life expectancy of communities owing to exposure to various environmental pollutants (Speldewinde et al., 2009; Truckner, 2009). This results from over consumption in society, where natural resources are utilised at an enormous rate while pollution is rampantly emitted. As a consequence, living a sustainable lifestyle is crucially important to balance 'need' versus the desire. Among issues addressed in sustainable development is food security. Food security focuses on various aspects that, among others, include the hygiene and safety of food consumed and the ecological footprint involved. It is a recent trend for environmentally conscious individuals to strive for a smaller footprint and demanding the safety of food consumed. Since the livestock sector, namely, meat providers, have been reported to contribute approximately $12.5 \%$ of greenhouse gases, which lead to global warming, more consumers are looking for alternative protein sources (McMichael et al., 2007; Rafiu et al., 2012; Zervas and Tsiplakou, 2012). This leads to the identification of aquatic food sources, i.e. seafood, as a good alternative source of protein. It has the potential to reduce dependency on meat from ungulates like cows and pigs.
Nevertheless, there are many factors to consider in the exploitation of these marine protein sources. Over the years, many issues have arisen, including overfishing and marine pollution. While overfishing issues are to be solved with appropriate policy and enforcement measures, marine pollution still threatens the safety of the marine food supply. The world has seen severe incidents that harm the marine environment, such as the Esson-Valdez oil spill in 1989 (Donohoe, 2003; Marty et al., 2003; Ricca et al., 2010). The impact was so severe that many studies were conducted to investigate options for remediating the pollution, essential to rehabilitate the destroyed ecosystem. Yet, many have failed to recognise the silent killer that exists in the marine world, i.e. the presence of persistent compounds, namely plastics, which have been accumulating in the marine environment since 1940s (Cole

Institute of Biological Sciences, University of Malaya, Kuala Lumpur, Malaysia

\section{Corresponding author:}

SH Fauziah, Institute of Biological Sciences, Faculty of Science, University of Malaya, Kuala Lumpur 50603, Malaysia.

Email: fauziahshđum.edu.my 
et al., 2011; O'Brine and Thompson, 2010). The fact that plastics are lightweight, non-degradable (and therefore durable), cheap, and easily producible, mean they have become massively popular among manufacturers and consumers. Unfortunately, the nondegradable and lightweight properties have made plastics one of the most problematic persistent pollutants in the marine environment. While the former feature ensures their lasting existence, the latter guarantees their wide dispersion in the marine environment. To make matters worse, physical fragmentation increases the negative impacts of plastics, as they are mistaken for plankton by marine organisms. As a result, microplastics enter the food chain and can potentially lead to bioaccumulation and biomagnificantion at higher trophic levels (Rochman et al., 2013). This could affect the survival of higher organisms in the marine environment, but also the provision of seafood for human consumption. Plastic components embedded in seafood could have detrimental health impacts if consumed by humans. Substances associated with plastics are carcinogenic (Jedrychowski et al., 2015) and have been identified as endocrine disruptors (Porte et al., 2006). Therefore, it is very important that plastics in particular, or rubbish in general, do not find their way into the marine environment. Once in the sea, these wastes are not 'the responsibility' of anyone. Therefore prevention, as usual, is better than cure, and it is imperative that waste flows are controlled appropriately, especially in the coastal environment.

Plastics debris can originate from both the terrestrial and marine environment. The former source includes plastic debris washed from land by surface runoff, from various anthropogenic activities including improper waste management and littering, and flooding events. Indonesia for example had to deal with some 91,529 t of waste after the flooding event in Jakarta in early 2014 (Jakarta Post, 2014). As for marine sources, plastic debris that arrives in the coastal environment arrives via the action of waves, and fishing and shipping activities, which carry waste materials from one continent to another. Regardless of where the plastics debris originates, the failure of proper waste management systems is the main contributing factor. The lack or absence of plastics recycling makes matters worse, since disposal into landfills can be very inefficient owing to plastics very low density nature, which together with poor landfill management, leads to poor containment. Additionally, if incinerated plastics can produce dioxin. Owing to these factors, plastic debris all too often ends up in the coastal environment. It is very important to monitor plastics debris in the coastal environment, so that appropriate and timely actions can be implemented to reduce the impacts it poses once introduced into the marine ecosystem, as well as to prevent waste reaching the sea in the first place. Even though various studies have been conducted on marine debris found along the beaches, little information has been compiled appropriately for absolute rather than relative quantification. Thus, so far, mainly only semiquantitative estimates of debris have been produced.

This study was conducted to quantify plastic debris buried in sand at selected beaches in Malaysia. Being a rapidly developing country, utilisation of plastic in Malaysia is highly visible. Thus, it is important to understand the impact of plastic waste in the environment, particularly the coastal environment. Therefore this study aims to determine the abundance of buried plastic debris according to size range and location. In order to identify the possible sources so that preventive actions can be recommended, classification of buried plastic debris based on sizes at these beaches was also conducted. Comparison of plastic waste abundance between recreational beaches and fish-landing beaches was also carried out to examine the relationship between beach use and amount and prevalence of debris types.

\section{Materials and methods}

The study areas included Port Dickson in Negeri Sembilan (West of Peninsular Malaysia), Kuala Terengganu in Terengganu (East of Peninsular Malaysia), and Kota Kinabalu in Sabah (East Malaysia). For each area, two sampling beaches were selected to represent a recreational beach and a fish-landing beach. Hence, a total of six sampling sites were selected and surveyed as indicated in Figure 1 and Table 1.

\section{Sampling design}

Plastic debris sampling was conducted once a month for three consecutive months (January, February, and March) with 28 days interval, as recommended by Lettenmaier (1978). The area of sampling spanned the low tide shoreline and high tide shoreline, which are within the foreshore zone to the berm and within the backshore zone, with a depth of $50 \mathrm{~mm}$ for each quadrat (Ryan et al., 2009).

Samples of plastics debris in beach sediment were collected during the low tide, within three belt transects, giving three sample replicates extending from the berm scarp to the low tide terrace (base of the foreshore). Moreover, the geographical position of the quadrat on the crest of the berm was used to re-establish the sampling areas each month using measuring tapes and stakes. At each site, triplicates of $12.5 \mathrm{~L}$ sediment consisting of sand or small gravel was scooped up using a small shovel within a $50 \times 50 \mathrm{~cm}^{2}$ quadrate (Figure 2) to a depth of approximately $5 \mathrm{~cm}$, from the low tide $(\mathrm{X})$ and the high tide $(\mathrm{Y})$ water level, as well as, from the berm area $(Z)$ of the beach within three belts transects. Hence, there were nine sampling points per beach site, as shown in Figure 3. Before scooping up the sand sample, any visible stranded litter was removed and the sample was placed into a bucket for analysis.

\section{Sieving of samples}

The sand in the bucket was mixed with seawater, stirred, and sieved through a set of nested sieves. The sieves were $200 \mathrm{~mm}$ in diameter with aperture sizes of $4.75 \mathrm{~mm}, 2.80 \mathrm{~mm}$, and $1.00 \mathrm{~mm}$, arranged in order of decreasing size from top to bottom. Particles, with an overall size range of $1-30 \mathrm{~mm}$, were retained from each sieve tray and placed in separate labelled plastic bags for sorting purposes. 


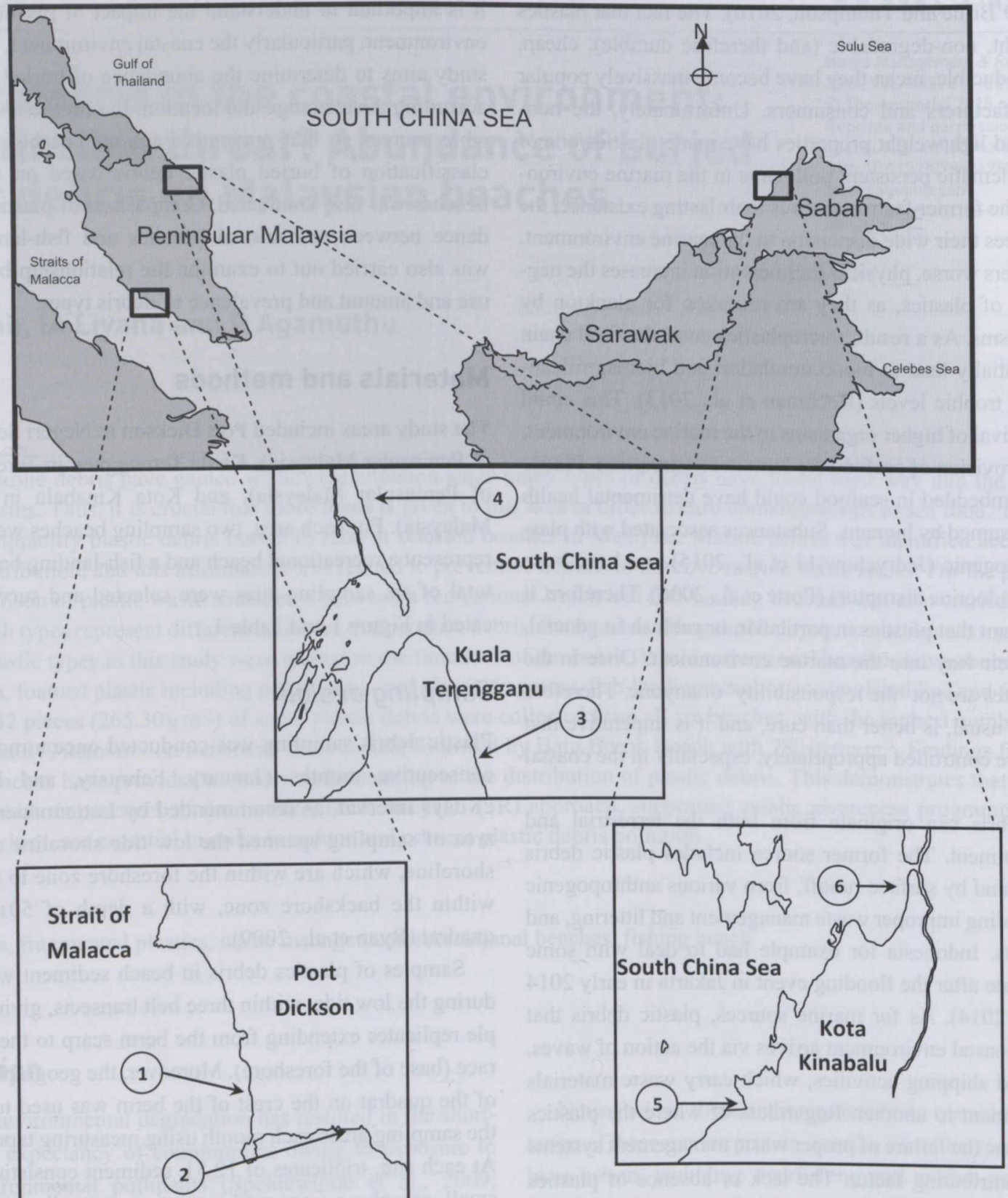

Figure 1. Locations of sampling sites on Malaysian beaches. Numbers correspond to location numbers.

Table 1. Sampling site coordinates.

Sampling sites

Pickson, Negeri Sembila

1. Teluk Kemang Beach (TK)

2. Pasir Panjang Beach (PP)

Kuala Terengganu, Terengganu

3. Batu Burok Beach (BB)

4. Seberang Takir Beach (ST)

Kota Kinabalu, Sabah

5. Tanjung Aru Beach (TA)

6. Teluk Likas Beach (TL)
Coordinates

Latitude

$2^{\circ} 27^{\circ} 19.14^{\prime \prime} \mathrm{N}$

$2^{\circ} 25^{\circ} 21.33^{\prime \prime} \mathrm{N}$

$101^{\circ} 51^{\prime} 18.47^{\prime \prime} \mathrm{E}$ $101^{\circ} 55^{\circ} 12.20^{\prime \prime} \mathrm{E}$

$5^{\circ} 19^{\prime} 21.83^{\prime \prime} \mathrm{N}$

$103^{\circ} 09^{\prime} 14.26^{\prime \prime} \mathrm{E}$ $103^{\circ} 07^{\prime} 51.20^{\prime \prime} \mathrm{E}$

$5^{\circ} 21^{\prime} 21.26^{\prime \prime} \mathrm{N}$

$116^{\circ} 02^{\prime} 48.00^{\prime \prime} \mathrm{E}$ $116^{\circ} 06^{\prime} 37.04^{\prime \prime} \mathrm{E}$ 


\section{Sorting of samples}

Samples were sorted according to the procedure proposed by Ogi and Fukumoto (2000) and Moore et al. (2001b), involving dry and wet sorting. Dry sorting from each sieve involved the separation of components into major categories; plastic, plant, and shell (McDermid and McMullen, 2004). Wet sorting included the procedure where each sub-sample was rinsed with water to get rid of any foreign materials - namely glass, paper, and ceramic materials, and transferred into a container of freshwater. It was then swirled for a minute and sieved to collect floating particles (mostly plastic). Samples were then oven dried for $1 \mathrm{~h}$ at $65^{\circ} \mathrm{C}$ (McDermid and McMullen, 2004).

\section{Classification and quantification}

After drying, plastic samples were separated, identified, and classified into film, foam, fragment, line, and pellet. These samples

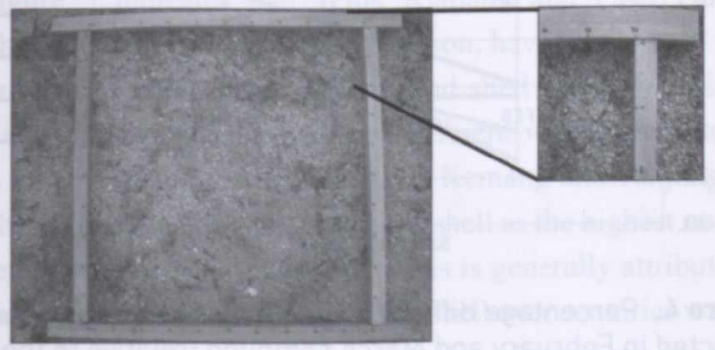

Figure 2. Sampling quadrat. were counted and recorded. In this study, the unit chosen was number of items/area (items $\mathrm{m}^{-2}$ ). Data obtained were input for statistical analysis.

\section{Results and discussions}

\section{Quantification of plastics debris on beaches}

Observations of the study area revealed that recreational beaches with a high density of beach users, and fishing beaches where fishermen dock and land their catch, have high exposure to human activities. All selected beaches were exposed to anthropogenic pressures via recreational activities, such as swimming, picnicking, and water skiing, and also fishing activities, including fish sorting, cleaning, and trading, as well as activities involving the maintenance of fishing gears (net and boats). Owing to the heavy burden of anthropogenic activities, all of the selected beaches recorded high quantities of plastic debris, as shown in Table 2.

Based on their location on the east coast of the Peninsular Malaysia, Batu Burok Beach and Seberang Takir Beach are expected to have the highest amount of plastic debris compared with other beaches. Plastic debris buried in the sand of these two beaches exceeded the average amount of debris in the beaches studied in the first month by $62 \%$. This is likely to be owing to the fact that these beaches are exposed to more intense wave currents and tides from the South China Sea. The South China Sea is also one of the busiest shipping routes, so plastic debris may also be contributed from the shipping sector. As a result, it is expected

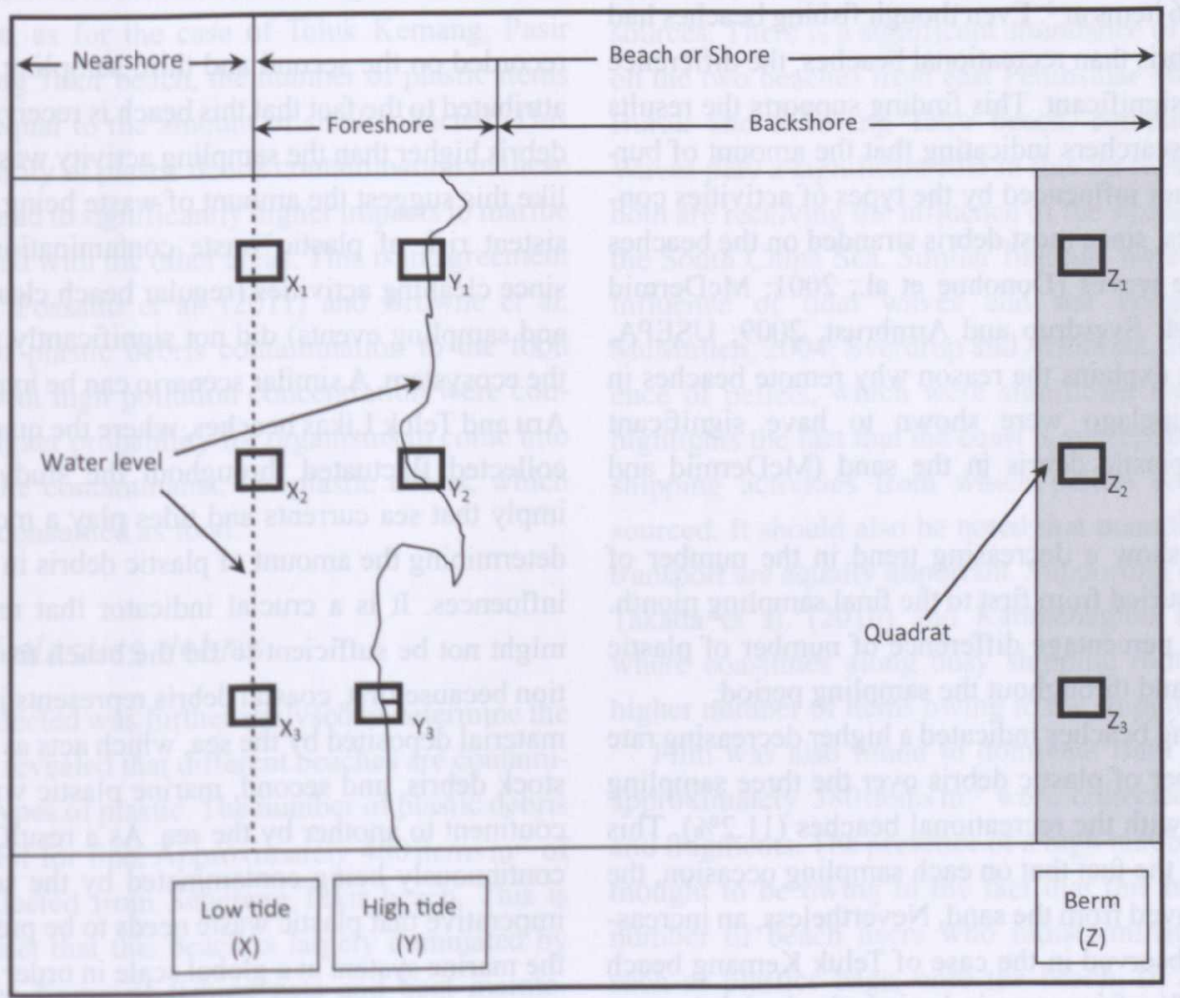

Figure 3. Nine points of sample per beach site (three replicates were determined within each water level and berm areal. 
Table 2. Average quantity of plastic debris (items $\mathrm{m}^{-2}$ ) in the three sampling events at the selected beaches.

\begin{tabular}{|c|c|c|c|c|}
\hline Sampling sites & Types of beach & Sampling 1 (items $\mathrm{m}^{-2}$ ) & Sampling 2 (items $\mathrm{m}^{-2}$ ) & Sampling 3 (items $\mathrm{m}^{-2}$ ) \\
\hline $\begin{array}{l}\text { Teluk Kemang Beach, Port } \\
\text { Dickson }\end{array}$ & Recreational & 219 & 244 & 229 \\
\hline $\begin{array}{l}\text { Pasir Panjang Beach, Port } \\
\text { Dickson }\end{array}$ & Fishing & 228 & 227 & 179 \\
\hline $\begin{array}{l}\text { Batu Burok Beach, Kuala } \\
\text { Terengganu }\end{array}$ & Recreational & 1064 & 888 & 388 \\
\hline $\begin{array}{l}\text { Seberang Takir Beach, Kuala } \\
\text { Terengganu }\end{array}$ & Fishing & 1164 & 944 & 528 \\
\hline $\begin{array}{l}\text { Tanjung Aru Beach, Kota } \\
\text { Kinabalu }\end{array}$ & Recreational & 183 & 213 & 180 \\
\hline $\begin{array}{l}\text { Teluk Likas Beach, Kota } \\
\text { Kinabalu }\end{array}$ & Fishing & 239 & 263 & 245 \\
\hline
\end{tabular}

that more plastic debris will be stranded here as compared with the other two areas. This agrees with findings by Karapanagioti and Klontza (2008). In addition to the busy shipping route, these two beaches also lack a regular cleaning programme.

While Port Dickson, Pasir Panjang, Tanjung Aru, and Teluk Likas are cleaned by the local council on a regular basis, Batu Burok and Seberang Takir beaches do not have such programmes. Consequently, the presence of a higher amount of plastic debris and stronger wave movement enable more physical fragmentation to occur, contributing to a greater number of plastic items in the area. This is in agreement with findings of other researchers on the influence of wave movement and waste distribution via sea currents (Golik and Gertner, 1992; McDermid and McMullen, 2004; Sverdrup and Armbrust, 2009).

It was found that the recreational beaches sampled had an

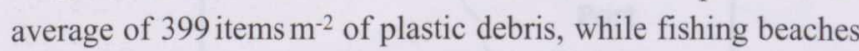
had an average of 446 items $^{-2}$. Even though fishing beaches had $12 \%$ more plastic debris than recreational beaches, the difference was not statistically significant. This finding supports the results reported by many researchers indicating that the amount of buried plastic debris is not influenced by the types of activities conducted on the beaches, since most debris stranded on the beaches is transported by the waves (Donohue et al., 2001; McDermid and McMullen, 2004; Sverdrup and Armbrust, 2009; USEPA, 1992). This situation explains the reason why remote beaches in the Hawaiian Archipelago were shown to have significant amounts of buried plastic debris in the sand (McDermid and McMullen, 2004).

The results also show a decreasing trend in the number of plastic debris items buried from first to the final sampling month. Figure 4 depicts the percentage difference of number of plastic items buried in the sand throughout the sampling period.

On average, fishing beaches indicated a higher decreasing rate $(13.5 \%)$ in the number of plastic debris over the three sampling events as compared with the recreational beaches $(11.2 \%)$. This is probably owing to the fact that on each sampling occasion, the plastic debris is removed from the sand. Nevertheless, an increasing trend was also observed in the case of Teluk Kemang beach where $2.3 \%$ and $2.2 \%$ of increase in buried plastic debris were

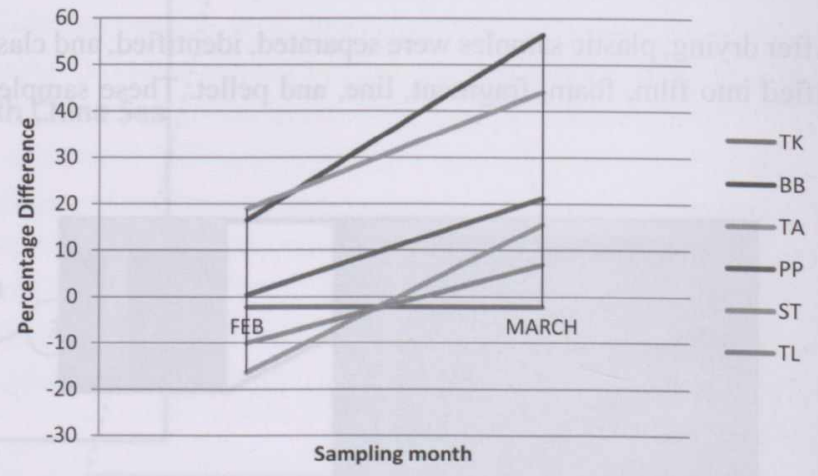

Figure 4. Percentage difference in amount of plastic debris collected in February and March sampling (relative to the preceding month).

TK: Teluk Kemang; BB: Batu Burok; TA: Tanjung Aru; PP: Pasir Panjang; ST: Seberang Takir; TL: Teluk Likas.

recorded on the second and third sampling event. This could be attributed to the fact that this beach is receiving an input of plastic debris higher than the sampling activity was removing. Scenarios like this suggest the amount of waste being input presents a consistent risk of plastic waste contamination of the food chain, since cleaning activities (regular beach cleaning by municipality and sampling events) did not significantly reduce its quantity in the ecosystem. A similar scenario can be hypothesised in Tanjung Aru and Teluk Likas beaches, where the quantity of plastic debris collected fluctuated throughout the study period. This might imply that sea currents and tides play a more significant role in determining the amount of plastic debris in the sand than human influences. It is a crucial indicator that regular cleaning alone might not be sufficient to rid the beach from plastic contamination because first, coastal debris represents just a small amount of material deposited by the sea, which acts as a larger repository or stock debris, and second, marine plastic waste travels from one continent to another by the sea. As a result, cleaned beaches are continuously being contaminated by the sea. Thus, it is highly imperative that plastic waste needs to be prevented from entering the marine system at a global scale in order to see a more significant result for beach cleaning efforts. 


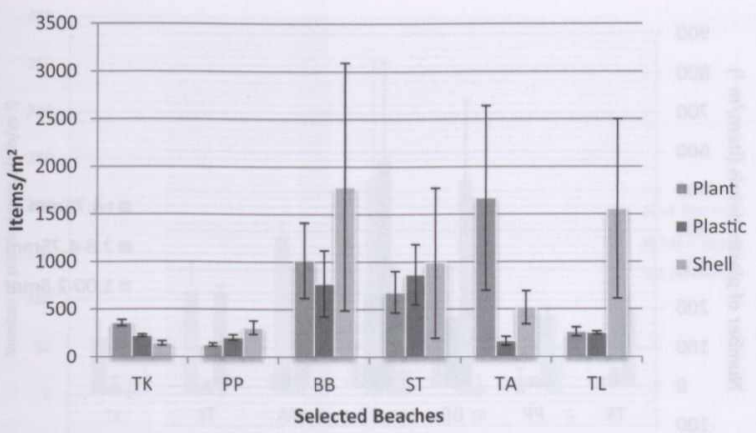

Figure 5. Number of items according to types in sand from selected beaches (error bars are the standard deviations). TK: Teluk Kemang: BB: Batu Burok; TA: Tanjung Aru; PP: Pasir Panjang; ST: Seberang Takir; TL: Teluk Likas.

Aside from plastic debris, plant and shell are the two major components found buried in the sand of study beaches. Figure 5 depicts the abundance of plant, plastic debris, and shell in the six beaches.

Figure 5 indicates that Teluk Kemang and Pasir Panjang beach, which are located in Port Dickson, have a relatively similar number of plant, plastic debris, and shell particles buried in the sand. On the other hand, very different values are obtained from other beaches. Except for Teluk Kemang and Tanjung Aru beach, all beaches were found to have shell as the highest number of items found buried in the sand. This is generally attributed to the fact that the constant supply of sea shell over centuries washed on shore by waves means that the number of items are generally higher as compared with plants material (from terrestrial sources) and plastics. In addition, the dense nature of sea shell makes it more prone to be deposited in the sand than being washed back to the sea. Nevertheless, as for the case of Teluk Kemang, Pasir Panjang, and Seberang Takir beach, the number of plastic items buried were almost equal to the amount of shell collected. This indicates that the severity of plastic debris contamination in these three beaches might lead to significantly higher impacts to marine organisms as compared with the other areas. This is in agreement with the findings of Possatto et al. (2011) and Browne et al. (2010) on the risk of plastic debris contamination to the food chain, where areas with high pollution concentration were considered to lead to a higher probability for organisms to come into direct contact with the contaminants, i.e. plastic debris, which could be mistakenly consumed as food.

\section{Classification of plastics debris}

The plastic debris collected was further analysed to determine the types of plastic. This revealed that different beaches are contaminated with different types of plastic. The number of plastic debris per $\mathrm{m}^{2}$ was the highest for line. Approximately 480 items m$^{-2}$ of plastic line were collected from Seberang Takir beach. This is likely owing to the fact that this beach is largely dominated by fishing activities. The fixing of fishing nets and boat maintenance, among other activities, are likely to have contributed to

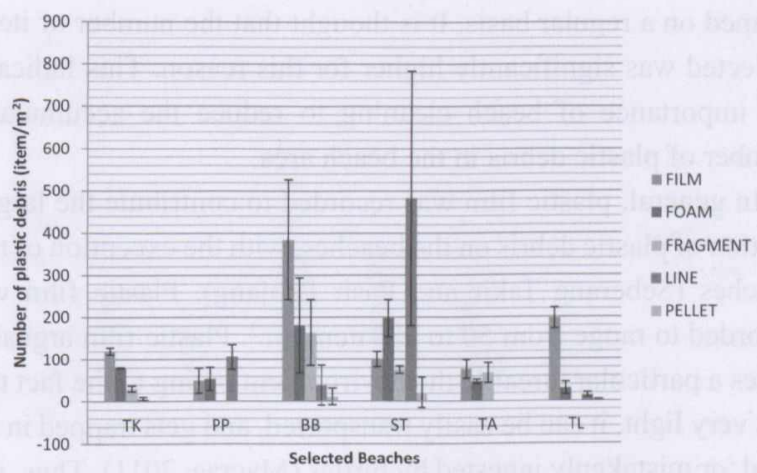

Figure 6. Types of plastic items (items $\mathrm{m}^{-2}$ ) collected at the beaches during the study period lerror bars are the standard deviations).

TK: Teluk Kemang; BB: Batu Burok; TA: Tanjung Aru; PP: Pasir Panjang; ST: Seberang Takir; TL: Teluk Likas.

the high quantity of plastic line in the area. Figure 6 illustrates the different types of plastic collected at the beaches during the study period.

The high abundance of line can be attributed to fishing activities owing to the scale of its manufacture, use and, in this particular case, discarding or loss (Browne et al., 2010). Net line and styrofoam fishing crates, particularly those used in fishing activity (sea-based) are thrown overboard and continue to float until washed ashore by the sea current. A similar scenario has been reported where fishing gear recovered in the Northwestern Hawaii Islands beach were lost during active fishing operations or intentional at-sea disposal, and were then transported by current to the beach (Donohue, 2005).

Apart from this, the other varieties of plastics in this study area were considered to come from both land- and sea-based sources. There is a significant abundance of various plastic types on the two beaches from east Peninsular Malaysia, namely Batu Burok and Seberang Takir beach, compared with the others. Waves play a significant role in this for these two beaches, since both are receiving the influence of the strong wind and current of the South China Sea. Similar findings were also reported on the influence of tidal waves and sea current (McDermid and McMullen, 2004; Sverdrup and Armbrust, 2009). As for the presence of pellets, which were significant for these beaches, this highlights the fact that the coast is susceptible to the influence of shipping activities from which pellets would most likely be sourced. It should also be noted that manufacturing and riverine transport are equally important. Supporting observations were by Takada et al. (2010) and Karapanagioti and Klontza (2008), where coastlines along busy shipping routes tend to receive a higher number of items owing to the shipping activities.

Film was also found to dominate Batu Burok beach, where approximately 380 items $\mathrm{m}^{-2}$ were collected, followed by foam and fragments. The presence of a high number of film plastic was thought to be owing to the fact that this beach receives a high number of beach users who indiscriminately discard plastics, such as plastics bags, onto the beach. In addition to that, this beach lacks regular beach cleaning, unlike other beaches that are 
cleaned on a regular basis. It is thought that the number of items collected was significantly higher for this reason. This indicates the importance of beach cleaning to reduce the accumulated number of plastic debris in the beach area.

In general, plastic film was recorded to contribute the largest portion of plastic debris on the beaches, with the exception of two beaches (Seberang Takir and Pasir Panjang). Plastic film was recorded to range from 50 to 384 items $\mathrm{m}^{-2}$. Plastic film arguably poses a particular threat to the environment owing to the fact that it is very light, it can be easily transported, and gets trapped in the sand, or mistakenly ingested by turtles (Macrae, 2011). Thus, it is crucially important to restrict the use of plastic film, for example plastic bags, in order to minimise its impacts on the coastal and marine environment.

Similarly foam, which is normally found as polystyrene, was found in all beaches from 15 to 200 items $^{-2}$. The abundance of this lightweight debris is owing to the deposition of foam on beaches from the water's edge, as well as it being deposited by wind. The exposure of the areas to the elements (wind and wave) and the characteristics of plastic debris both influence the transport and residence time of debris items in the study area. Thiel et al. (2003) reported that permanence of plastic debris cast ashore may vary depending on its weight and size. Consequently, lightweight debris (e.g. styrofoam) may be blown away from the flotsam to the beach. This indicates the threat foam plastic poses to all coastal environments where, regardless of the activities and efforts taken, beaches are easily contaminated with this types of debris.

\section{Size range and location}

Because size plays a significant role in the risk posed to the marine ecosystem, plastic debris were also investigated based on its size range. The most predominant size of plastic debris on these beaches was more than $4.75 \mathrm{~mm}$. It is believed that this is because of the continuous disposal of whole plastic waste, which takes a certain period to undergo fragmentation into pieces. Figure 7 depicts the size range of the plastic debris on the beaches in Malaysia.

The highest number of items was observed in the largest size category in all the beaches. The range in this category was from

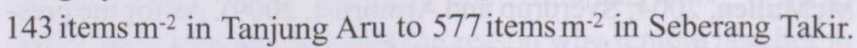
The larger debris $(>4.75 \mathrm{~mm})$ was particularly abundant in Seberang Takir and Batu Burok beaches. This is thought to be owing to the absence of regular beach cleaning, so most debris discarded or washed onto the beach will remain there. The next most abundant category is the size range of $2.8 \mathrm{~mm}$ to $4.75 \mathrm{~mm}$. The smallest range within the small plastic debris categories, i.e. $1.00 \mathrm{~mm}$ to $2.8 \mathrm{~mm}$, was recorded as the least abundant. This could be because the degradation of plastic into smaller fragments requires a longer period than the residence time on the beach. Nevertheless, it also should be noted that the number might be small owing to the consumption by the indigenous organisms that mistaken the fine debris as food.

Aside from the size range, the distribution of the plastic debris along the belt transect is also important to understand its

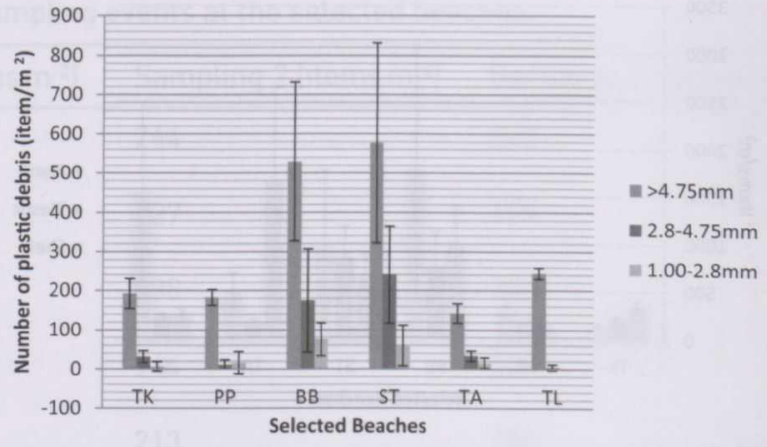

Figure 7. Number of small plastic debris according to size found on beaches in Malaysia lerror bars are the standard deviations).

TK: Teluk Kemang; BB: Batu Burok; TA: Tanjung Aru; PP: Pasir Panjang; ST: Seberang Takir; TL: Teluk Likas.

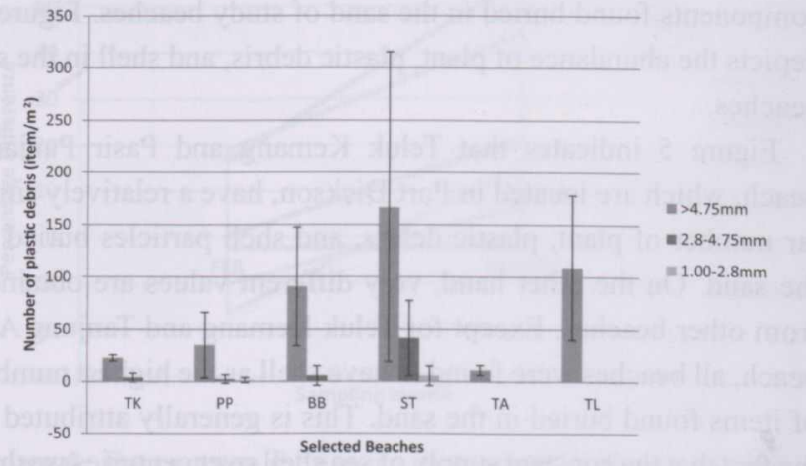

Figure 8. Number of items according to size range found within the low tide region of Malaysian beaches lerror bars are the standard deviations).

TK: Teluk Kemang; BB: Batu Burok; TA: Tanjung Aru; PP: Pasir Panjang: ST: Seberang Takir; TL: Teluk Likas.

impacts on the environment, as different strata of the beach are occupied by different groups of fauna. The most prevalent size category within the low tide strata is $>4.75 \mathrm{~mm}$. This trend is observed in all of the beaches. It is followed by items within the range of $2.8 \mathrm{~mm}$ to $4.75 \mathrm{~mm}$. However, the two beaches from East Malaysia, namely Tanjung Aru and Teluk Likas, were free of debris smaller than $4.75 \mathrm{~mm}$ within the low tide strata.

Similar observation was obtained for items ranging from $1.00 \mathrm{~mm}$ to $2.8 \mathrm{~mm}$ in the low tide area of the four beaches. It indicates that the finer debris was unlikely to accumulate within the low tide region. This could be owing to the tidal waves constantly washing the finer debris away from the area. Figure 8 illustrates the size of debris found within the low tide region.

Within the high tide region, debris was found in all size ranges. Debris larger than $4.75 \mathrm{~mm}$ was found again to be significantly more abundant than the finer debris. It ranged from 26 to 230 items m$^{-2}$ within the high tide region. This could be explained by the larger volume of water with the capability to transport and deposit larger debris reaching this area, thus influencing the distribution of plastic debris in this region. This scenario had been previously reported (Corcoran et al., 2009; Storrier et al., 2007). 


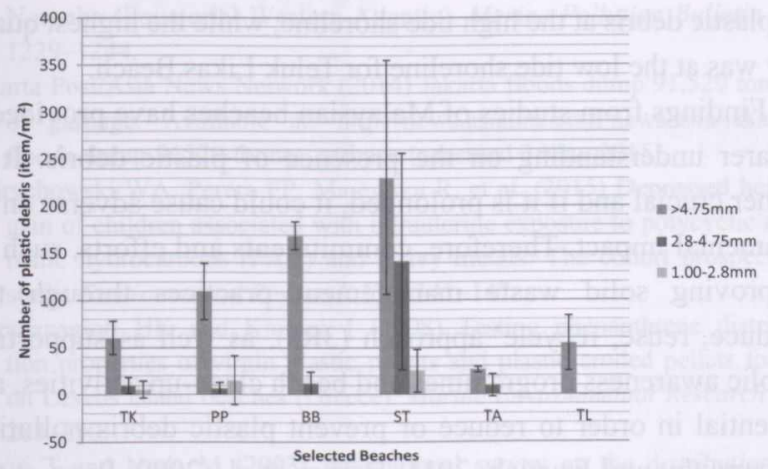

Figure 9. Number of plastic debris according to size within the high tide region in Malaysian beaches lerror bars are the standard deviationsl.

TK: Teluk Kemang; BB: Batu Burok; TA: Tanjung Aru; PP: Pasir Panjang; ST: Seberang Takir; TL: Teluk Likas.

Except for Seberang Takir with heavy fishing activities, in the high tide region, all of the beaches had a significantly lower number of plastic items that ranged from $2.8 \mathrm{~mm}$ to $4.75 \mathrm{~mm}$. This trend continued for items ranging from $1.00 \mathrm{~mm}$ to $2.8 \mathrm{~mm}$. This could be because the degradation of plastic into smaller fragments requires a longer period than the residence time at the high tide level. Additionally, it could be owing to the prevalence of heavier fragments that were washed ashore. As expected, heavier (but more buoyant) debris is more likely to be deposited where waves end and recede (Thornton and Jackson, 1998). Figure 9 shows the distribution of plastic debris according to size within the high tide region.

As compared with high tide and low tide, the berm area has the highest number of accumulated plastic debris sized more than

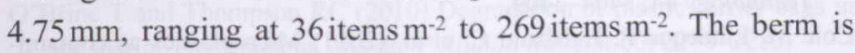
often composed of sand, making it favourable for beachgoers, therefore, the great quantity of plastic debris along the berm might be owing to the littering of plastics by beach users. Rees and Pond (1995) also had reported a similar finding in the beaches of the British Isles. The results also indicate that the small plastic debris buried along the berm area are mainly larger than $4.75 \mathrm{~mm}$. Figure 10 illustrates the number of plastic debris items according to size in the berm area.

It was found that finer debris in the $2.8 \mathrm{~mm}$ to $4.75 \mathrm{~mm}$ size ranging was also significant in the berm area. This might be a result of fragmentation of plastic debris owing to the combination of chemical weathering and mechanical eroding of plastic, and longer residence time. Plastic degradation on Kauai beach in Hawaii was thought to be owing to chemical weathering processes, such as photothermal oxidation caused by solar ultraviolet radiation, leading to a reduction in the mechanical strength of the plastic materials (Corcoran et al., 2009; Gregory and Andrady, 2003). Additional abrasion exposure from sand grains dragging across plastic surfaces also resulted in mechanical erosion and breakages along fractures (Corcoran et al., 2009). As in this study, finer debris were more abundant in the berm area, and a low rate of exportation from the area, lead to an accumulation of items in the smaller size category.

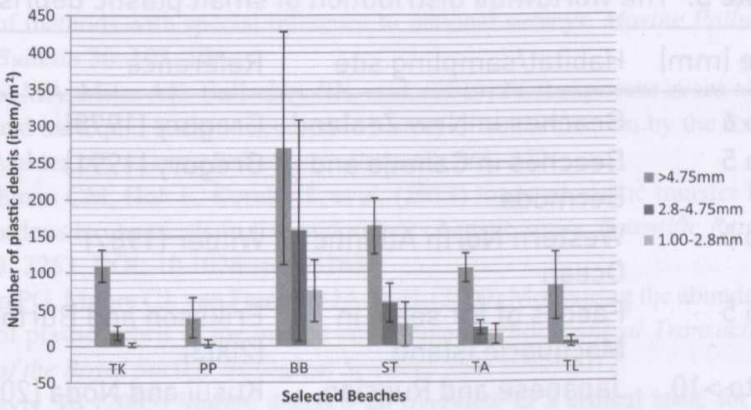

Figure 10. Number of plastic debris according to size within the berm area in Malaysian beaches lerror bars are the standard deviations).

TK: Teluk Kemang; BB: Batu Burok; TA: Tanjung Aru; PP: Pasir Panjang: ST: Seberang Takir; TL: Teluk Likas.

Small plastic debris between 1 and $30 \mathrm{~mm}$ in size occurred on all of the transect belts of the beaches. Debris with size more than $4.75 \mathrm{~mm}$ were the most abundant $(73 \%)$, followed by debris which ranged from 2.80 to $4.75 \mathrm{~mm}$ ( $20 \%$ ), while 1.00 to $2.80 \mathrm{~mm}$ $(7 \%)$ was the least abundant in all beaches.

The presence of 2542 pieces $\left(265.30 \mathrm{~g} \mathrm{~m}^{-2}\right)$ of plastic debris on the studied beaches is similar to the results reported by McDermid and McMullen (2004) at nine beaches throughout the Hawaiian archipelago, which recorded 19,100 pieces of plastic debris. However, the contrasting aspect is that the Hawaiian plastic debris was found on remote Hawaiian beaches that lack dense human population or shipping traffic, while for Malaysian beaches heavily used beaches were assessed.

Plastics debris on the Hawaiian archipelago probably originated from exogenous sources and were possibly transported via ocean gyres, winds, and sea currents before being washed ashore (Allsopp et al., 2006; Corbin and Singh, 1993; McDermid and McMullen, 2004; Moore et al., 2001a; Sheavly, 2005). The distribution of plastic debris on Malaysian beaches could be attributed to heavy anthropogenic activities (mostly fishing and recreation).

Findings from Malaysian beaches indicated that beach activities are contributing to plastic debris deposition. Though no similar study is available to support or disagree with this finding, the distribution of different plastic types (581 items $\mathrm{m}^{-2}$ of film in recreational areas and 602 items $\mathrm{m}^{-2}$ of line in fishing areas) within the studied beaches showed that beach activity influenced plastic debris distribution.

Generally, there are various sizes of plastic debris buried in Malaysian beaches. It ranged from 1 to $30 \mathrm{~mm}$ for all plastic types, which are agreeable with results obtained in beaches around the world (McDermid and McMullen, 2004; SilvaCavalcanti et al., 2009). Table 3 shows the worldwide distribution of small plastic debris. The distribution reported in Table 3 indicates the relative abundance of small plastic debris buried in $5 \mathrm{~cm}$ deep sand of the selected beaches. This indicates that the ranges of buried plastic debris are dependent on the activities conducted on the beaches. 
Table 3. The worldwide distribution of small plastic debris.

\begin{tabular}{|c|c|c|}
\hline Size $(\mathrm{mm})$ & Habitat/sampling site & Reference \\
\hline 4 to 6 & Beaches in New Zealand & Gregory (1978) \\
\hline 1 to 5 & $\begin{array}{l}\text { Beaches in Canada and } \\
\text { Bermuda }\end{array}$ & Gregory (1991) \\
\hline 2 to 5 & $\begin{array}{l}\text { Western North Atlantic } \\
\text { Ocean }\end{array}$ & Wilber (1987) \\
\hline 2 to 5 & $\begin{array}{l}\text { Faeces of fur seals in } \\
\text { Macquarie Island }\end{array}$ & $\begin{array}{l}\text { Eriksson and Burton } \\
\text { (2003) }\end{array}$ \\
\hline$<1$ to $>10$ & $\begin{array}{l}\text { Japanese and Russian } \\
\text { beaches, Sea of Japan }\end{array}$ & Kusui and Noda (2003) \\
\hline 1 to 15 & Beaches in Hawaii & $\begin{array}{l}\text { McDermid and } \\
\text { McMullen (2004) }\end{array}$ \\
\hline$\sim 2$ & $\begin{array}{l}\text { Beaches, coastal } \\
\text { sediments, and } \\
\text { invertebrates in UK }\end{array}$ & Thompson et al. (2004) \\
\hline$>0.16$ & $\begin{array}{l}\text { Beaches and coastal } \\
\text { waters in Singapore }\end{array}$ & $\mathrm{Ng}$ and Obbard (2006) \\
\hline 2 to 20 & $\begin{array}{l}\text { Beaches, Fernando de } \\
\text { Noronha }\end{array}$ & Ivar do Sul et al. (2009) \\
\hline 2 to 5 & $\begin{array}{l}\text { Archipelago, Equatorial } \\
\text { Atlantic }\end{array}$ & Ivar do Sul et al. (2009) \\
\hline 1 to 20 & $\begin{array}{l}\text { Boa Viagem beach in } \\
\text { Brazil }\end{array}$ & $\begin{array}{l}\text { Silva-Cavalcanti et al. } \\
\text { (2009) }\end{array}$ \\
\hline 1 to 30 & Beaches in Malaysia & This report \\
\hline
\end{tabular}

\section{Conclusions}

This study was designed to investigate the abundance of small plastic debris buried in the sands at six sampling sites on Malaysian beaches. The beaches were selected to represent recreational and fishing areas. The abundance of small plastics in these study areas originated from anthropogenic activities (mostly fishing and recreational), which are both land-based and sea-based.

A total of 2542 pieces $\left(265.30 \mathrm{~g} \mathrm{~m}^{-2}\right)$ of small plastic debris were collected from all six beaches. The greatest quantity was

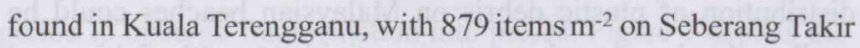
Beach, followed by Batu Burok Beach with 780 items $\mathrm{m}^{-2}$. The other four beaches had lower quantities, which ranged from 192 items $\mathrm{m}^{-2}$ to 249 items $\mathrm{m}^{-2}$.

The abundance of plastic debris within different types of classification are different depending on the functions of the beach. Recreational beaches, namely Teluk Kemang Beach, Batu Burok Beach, and Tanjung Aru Beach, have an abundance of plastic film, foam, and fragment, whereas predominant types of plastics found in fishing beach areas (Pasir Panjang Beach, Seberang Takir Beach, and Teluk Likas Beach) included line, foam, and film. Plastic pellets were present only in three study areas, namely Batu Burok Beach, Seberang Takir Beach, and Teluk Likas Beach.

Recreational beaches (Teluk Kemang Beach, Batu Burok Beach, and Tanjung Aru Beach) have most abundance of the smaller size categories of plastic debris at the berm location, whereas along the fishing beaches, smaller plastic debris was most abundant at the foreshore area (low tide and high tide). Pasir Panjang Beach and Seberang Takir Beach had the highest quantity of plastic debris at the high tide shoreline, while the highest quantity was at the low tide shoreline for Teluk Likas Beach.

Findings from studies of Malaysian beaches have provided a clearer understanding on the presence of plastic debris. It is rather crucial and if it is prolonged, it could cause adverse environmental impact. Therefore, commitments and efforts, such as improving solid waste management practices through the 'reduce, reuse, recycle' approach (3Rs), as well as supporting public awareness programmes and beach clean-up activities, are essential in order to reduce or prevent plastic debris pollution (Agamuthu and Fauziah, 2011; Barnes et al., 2009; Ryan et al., 2009; UNEP, 2009).

\section{Declaration of conflicting interests}

The authors declare that there is no conflict of interest.

\section{Funding}

Authors would like to acknowledge University of Malaya for the research grant provided (PG125-2012B).

\section{References}

Agamuthu P and Fauziah SH (2011) Challenges and issues in moving towards sustainable landfilling in a transitory country - Malaysia. Waste Management \& Research 29: 13-19.

Allsopp M, Walters A, Santillo D, et al. (2006) Plastic Debris in the World's Oceans. Available at: http://www.greenpeace.org/international/en/publications/reports/plastic_ocean_report/ (accessed 2 June 2010).

Barnes DKA, Galgani F, Thompson RC, et al. (2009) Accumulation and fragmentation of plastic debris in global environments. Philosophical Transactions of the Royal Society Biology 364: 1985-1998.

Browne MA, Galloway TS and Thompson RC (2010) Spatial patterns of plastic debris along estuarine shorelines. Environmental Science and Technology 44: 3404-3409.

Cole M, Lindeque P, Halsband C, et al. (2011) Microplastics as contaminants in the marine environment: A review. Marine Pollution Bulletin 62: $2588-2597$.

Corbin CJ and Singh JG (1993) Marine debris contamination of beaches in St. Lucia and Dominica. Marine Pollution Bulletin 26: 325-328,

Corcoran PL, Biesinger MC and Grifi M (2009) Plastics and beaches: A degrading relationship. Marine Pollution Bulletin 58: 80-84.

Donohue MJ, Boland RC, Sramek CM, Antonelis GA (2001) Derelict fishing gear in the Northwestern Hawaiian Islands: Diving surveys and debris removal in 1999 confirm threat to coral reef ecosystems. Marine Pollution Bulletin 42(12): 1301-1312.

Donohoe M (2003) Causes and health consequences of environmental degradation and social injustice. Social Science \& Medicine 56: 573-587.

Donohue MJ (2005) Eastern Pacific Ocean source of Northwestern Hawaiian Islands marine debris supported by errant fish aggregating device. Marine Pollution Bulletin 50: 886-888.

Eriksson C and Burton H (2003) Origins and biological accumulation of small plastic particles in fur seals from Macquarie Island. Ambio 32: 380-384.

Golik A and Gertner Y (1992) Litter on the Israeli coastline. Marine Environmental Research 33: 1-15.

Gregory MR (1978) Accumulation and distribution of virgin plastic granules on New Zealand beaches. New Zealand Journal of Marine and Freshwater Research 12:399-414.

Gregory MR (1991) The hazards of persistent marine pollution: Drift plastics and conservation islands. Journal of the Royal Society of New Zealand 21: 83-100.

Gregory MR and Andrady AL (2003) Plastics in the marine environment. In: Andrady AL (ed.) Plastics and the Environment. New Jersey, USA: John Wiley \& Sons, $379-401$.

Ivar do Sul JA, Spengler A and Costa MF (2009) Here, there and everywhere. Small plastic fragments and pellets on beaches of Fernando de 
Noronha (Equatorial Western Atlantic). Marine Pollution Bulletin 58: $1229-1244$.

Jakarta Post/Asia News Network (2014) Jakarta floods dump 91,529 tonnes of garbage. Available at: http://news.asiaone.com/news/asia/jakartafloods-dump-91529-tonnes-garbage (accessed 3 May 2015).

Jedrychowski WA, Perera FP, Majewska R, et al. (2015) Depressed height gain of children associated with intrauterine exposure to polycyclic aromatic hydrocarbons $(\mathrm{PAH})$ and heavy metals: The cohort prospective study. Environmental Research 136: 141-147.

Karapanagioti HK and Klontza I (2008) Testing phenanthrene distribution properties of virgin plastic pellets and plastic eroded pellets found on Lesvos island beaches (Greece). Marine Environmental Research 65: 283-290.

Kusui T and Noda M (2003) International survey on the distribution of stranded and buried litter on beaches along the Sea of Japan. Marine Pollution Bulletin 47: 175-179.

Lettenmaier DP (1978) Design considerations for ambient stream quality monitoring. Water Resource Bulletin 14: 884-902.

Macrae F (2011) Killed by pollution: Hundreds of pieces of plastic found inside stomach of sea turtle. Daily Mail. Available at: www.dailymail. co.uk >article-1369438 (accessed 3 May 2015).

Marty GD, Hoffmann A, Okihiro MS, et al. (2003) Retrospective analysis: Bile hydrocarbons and histopathology of demersal rockfish in Prince William Sound, Alaska, after the Exxon Valdez oil spill. Marine Environmental Research 56: 569-584.

McDermid KJ and McMullen TL (2004) Quantitative analysis of smallplastic debris on beaches in the Hawaiian archipelago. Marine Pollution Bulletin 48: 790-794.

McMichael AJ, Powles JW, Butler CD, et al. (2007) Food, livestock production, energy, climate change, and health. The Lancet 370: $1253-1263$.

Moore CJ, Moore SL, Leecaster MK, et al. (2001a) A comparison of plastic and plankton in the North Pacific central gyre. Marine Pollution Bulletin 42: $1297-1300$.

Moore SL, Gregorio D, Carreon M, et al. (2001b) Composition and distribution of beach debris in Orange County, California. Marine Pollution Bulletin 42: 241-245.

$\mathrm{Ng} \mathrm{KL}$ and Obbard JP (2006) Prevalence of microplastics in Singapore's coastal marine environment. Marine Pollution Bulletin 52: 761-767.

O'Brine T and Thompson RC (2010) Degradation of plastic carrier bags in the marine environment. Marine Pollution Bulletin 60: 2279-2283.

Ogi H and Fukumoto Y (2000) A sorting method for small plastic debris floating on the sea surface and stranded on sandy beaches. Bulletin of the Faculty of Fisheries, Hokkaido University 51: 71-93.

Porte C, Janer G, Lorusso LC, et al. (2006) Endocrine disruptors in marine organisms: Approaches and perspectives. Comparative Biochemistry and Physiology Part C: Toxicology \& Pharmacology 143: 303-315.

Possatto FE, Barletta M, Costa MF, et al. (2011) Plastic debris ingestion by marine catfish: An unexpected fisheries impact. Marine Pollution Bulletin 62(5): 1098-1102.

Rafiu OY, Zainura ZN, Ahmad HA, et al. (2012) Methane emission by sectors: A comprehensive review of emission sources and mitigation methods. Renewable and Sustainable Energy Reviews 16(7): 5059-5070.
Rees G and Pond K (1995) Marine litter monitoring programmes - A review of methods with special reference to national surveys. Marine Pollution Bulletin 30: 103-108.

Ricca MA, Miles AK, Ballachey BE, et al. (2010) PCB exposure in sea otters and harlequin ducks in relation to history of contamination by the Exxon Valdez oil. Marine Pollution Bulletin 60: 861-872.

Rochman CM, Hoh E, Korube T, et al. (2013) Ingested plastic transfer haz ardous to chemicals to fish and induces hepatic stress. Scientific Reports 3: 3263. DOI: $10.1038 / \mathrm{srep} 03263$.

Ryan PG, Moore CJ, van Franeker JA, et al. (2009) Monitoring the abundance of plastic debris in the marine environment. Philosophical Transactions of the Royal Society Biological Sciences 364: 1999-2012.

Sheavly SB (2005) Marine debris - an overview of a critical issue for our oceans. In: 6th meeting of the UN open-ended informal consultative processes on oceans \& the law of the sea, New York, 6-10 June 2005 Available at: http://www.un.org/Depts/los/consultative_process/consultative_process.htm (accessed 2 June 2010).

Silva-Cavalcanti JS, Barbosa de Araújo MC, Ferreira da Costa M (2009) Plastic litter on an urban beach- A case study in Brazil. Waste Management and Research 27: 93-97.

Speldewinde PC, Cook A, Davies P, et al. (2009) A relationship between environmental degradation and mental health in rural Western Australia Health \& Place 15: 880-887.

Storrier KL, McGlashan DJ, Bonellie S, et al. (2007) Beach litter deposition at a selection of beaches in the firth of forth, Scotland. Journal of Coastal Research 23: 813-822.

Sverdrup KA and Armbrust EV (2009) An Introduction to the World's Oceans. New York: McGraw-Hill Higher Education.

Takada H, Mato Y, Endo S, et al. (2010) Pellet watch: Global monitoring of persistent organic pollutants (POPs) using beached plastic resin pellets. Available at: http://www.tuat.ac.jp/ gaia/ipw/documents/takadaproceeding.pdf (accessed 11 November 2010).

Thiel M, Hinojosa I, Vásquez N, et al. (2003) Floating marine debris in coasta waters of the SE-Pacific (Chile). Marine Pollution Bulletin 46: 224-231.

Thompson RC, Olsen Y, Mitchell RP, et al. (2004) Lost at sea: Where is all the plastic? Science 304: 838 .

Thornton L and Jackson NL (1998) Spatial and temporal variations in debris accumulation and composition on an estuarine shoreline, Cliffwood Beach, New Jersey, USA. Marine Pollution Bulletin 36: 705-711.

Truckner RT (2009) Health care provider beliefs concerning the adverse health effects of environmental and ecosystem degradation. Wilderness \& Environmental Medicine 20: 199-211.

UNEP (April 2009). Marine Litter: A Global Challenge. Nairobi: UNEP. Available at: http://www.unep.org/regionalseas/marinelitter/publications/docs/MarineLitterGlobalChallenge.pdf (accessed 12 July 2010).

USEPA (1992). Plastic Pellets in the Aquatic Environment: Sources and Recommendations. United States Environmental Protect Agency Office of Water. Available at: http://www.mindfully.org/Plastic/Ocean/PlasticAquatic-EPA842B92010-Dec92 ES.htm (accessed 25 September 2014). Wilber RJ (1987) Plastic in the North Atlantic. Oceanus 30: 61-68.

Zervas G and Tsiplakou E (2012) An assessment of GHG emissions from small ruminants in comparison with GHG emissions from large ruminants and monogastric livestock. Atmospheric Environment 49: 13-23. 